\title{
IDENTIFICATION OF STUDENTS METACOGNITION LEVELS IN PROBLEM-SOLVING AND MATHEMATICAL LITERACY
}

\section{IDENTIFIKASI TINGKAT METAKOGNISI SISWA DALAM PEMECAHAN MASALAH DAN LITERASI MATEMATIKA}

\author{
Maya Trisnani ${ }^{1}$, Widodo Winarso ${ }^{2}$ \\ ${ }^{1,2}$ (Tadris Matematika, Fakultas Ilmu Tarbiyah dan Keguruan, IAIN Syekh Nurjati Cirebon, Indonesia) \\ Imayatrisnani1@gmail.com,2widodoiain@gmail.com
}

\begin{abstract}
Metacognition is knowledge and awareness about the process of cognition or learning about the mind and how it works. Solving mathematical problems requires the involvement of metacognition. This study aims to obtain the results of identification of students' level of metacognition in problem-solving and the level of metacognition of students in mathematical literacy on social arithmetic material. This research was conducted at SMP Negeri 3 Palimanan. This type of research is qualitative research. The subjects of this study were students of class VII C Middle School 3 Palimanan. Data collected by test and interview methods. Data were analyzed using data reduction, data presentation, and concluding. The results of this study indicate that the level of metacognition of students in solving mathematical problems and mathematical literacy has mixed results. In solving mathematical problems, students who have high learning outcomes are at the level of Reflective Use metacognition, students who have learning outcomes are at the Strategic Use metacognition level, and students who have low learning outcomes are at the Tacit Use metacognition level. Meanwhile, the level of student metacognition in mathematics literacy is not much different from solving mathematical problems. Students who have high learning outcomes are at the Reflective Use metacognition level, students who have learning outcomes are at the Strategic Use metacognition level, and students who have low learning outcomes are at the Aware Use metacognition level. Overall the level of metacognition of students both in solving mathematical problems and in mathematics literacy is at the level of Strategic Use metacognition.
\end{abstract}

Keywords :Metacognition, Problem Solving, Mathematical Literacy

\begin{abstract}
ABSTRAK
Metakognisi merupakan pengetahuan dan kesadaran tentang proses kognisi atau pengetahuan tentang pikiran dan cara kerjanya. Dalam menyelesaikan persoalan matematika memerlukan keterlibatan metakognisi. Penelitian ini bertujuan untuk memperoleh hasil identifikasi tingkat metakognisi siswa pada pemecahan masalah dan tingkat metakognisi siswa pada literasi matematika pada materi aritmetika sosial. Penelitian ini dilakukan di SMP Negeri 3 Palimanan. Jenis penelitian ini adalah penelitian kualitatif. Subjek penelitian ini adalah siswa kelas VII C SMP Negeri 3 Palimanan. Data dikumpulkan dengan metode tes dan wawancara. Data dianalisis dengan menggunakan reduksi data, penyajian data, dan penarikan kesimpulan. Hasil penelitian ini menunjukkan bahwa tingkat
\end{abstract}


metakognisi siswa dalam pemecahan masalah matematika dan literasi matematika memiliki hasil yang beragam. Pada pemecahan masalah matematika, siswa yang mempunyai hasil belajar tinggi berada pada tingkat metakognisi Reflective Use, siswa yang mempunyai hasil belajar sedang berada pada tingkat metakognisi Strategic Use, dan siswa yang mempunyai hasil belajar rendah berada pada tingkat metakognisi Tacit Use. Sementara itu tingkat metakognisi siswa dalam literasi matematika tidak jauh berbeda dengan pemecahan masalah matematika. Siswa yang mempunyai hasil belajar tinggi berada pada tingkat metakognisi Reflective Use, siswa yang mempunyai hasil belajar sedang berada pada tingkat metakognisi Strategic Use, dan siswa yang mempunyai hasil belajar rendah berada pada tingkat metakognisi Aware Use. Secara keseluruhan tingkat metakognisi siswa baik dalam pemecahan masalah matematika maupun dalam literasi matematika berada pada tingkat metakognisi Strategic Use.

Kata Kunci :Metakognisi, Pemecahan Masalah, Literasi Matematika

\section{INTRODUCTION}

Mathematics is a science that must be mastered by students in the 21 st century (Gardner, 2000). Mastery of mathematics is certainly a demand for students as a millennial generation to be able to compete in global competition. Along with the development of science and technology, mathematics has made a significant contribution to contributing ideas and concepts needed in every development (Murtiyasa, 2016)

Mathematics learning is very closely related to problem-solving activities. Problem-solving activities are one of the main events in learning mathematics (Karamarski, 2017). Learning activities can be said to be going well and according to the demands of the 2013 Curriculum, if educators can present teaching materials by implementing student-centered learning strategies, one of which is learning by solving problems (Winarso, 2014). This problem-solving activity is fundamental so that students can foster logical, creative, and systematic thinking (Yarmayani, 2016).

However, in reality, there are still students who have difficulty in solving mathematical problems. This was as revealed by Alfiyah (2014) in his research on identifying the metacognition difficulties of students in solving mathematical problems which showed that students' abilities were still low in solving mathematical problems. In line with that, Suraji, Maimunah, \& Saragih (2018) argued that the strength of problem-solving and the ability to understand mathematical concepts of students are still relatively low, especially in the application of daily life. 
In connection with this statement, Khoirudin, Setyawati, \& Nursyahida (2017) explained that the low problem-solving activities of students can be influenced by several factors, including those related to the material chosen, learning provided by the teacher, class environment, family environment support, readiness in implementation each student's tests and abilities.

Furthermore, Setia in Nuurjannah (2018) argues that some internal factors of students can also influence students' problem-solving abilities. Among these internal factors are the level of intelligence (intellectual), attention, interest, talent, motivation, maturity, and readiness. Related to one's knowledge, each student has different thinking and cognitive abilities (Kazemi, Yektayar \& Abad, 2012). This includes the ability of students to realize their thought processes. Awareness about this thought process is known as metacognition.

John Flavell first introduced the term metacognition in 1976. According to Flavell (1976), metacognition is defined as awareness, consideration, and control of the processes and strategies of cognition. Correspondingly, Matlin (2009) suggests that metacognition is a person's knowledge, awareness, and control of their cognitive processes and can assist in selecting problem-solving strategies. Metacognition has an essential role in learning mathematics, especially in solving mathematical problems (Schoenfeld, 1992).

According to Polya (1973), problem-solving is the presentation of a solution to a problem that must be resolved. Polya also revealed the four steps of the settlement phase, namely understanding the problem, planning the solution, solving the issue according to the plan, and re-checking all the stages that had been done.

Social arithmetic is one of the mathematical material taught to students in grade VII SMP / MTs. The scope of this material is mostly related to daily problems that are often encountered. Forms of questions on social arithmetic material are usually in the way of story problems. According to Merlina (2013) in solving the issue of the form of the story needed the ability of problem-solving, namely how to solve a problem in stages by the steps that have been set. This problem-solving ability is closely related to mathematical literacy (Ojose, 2011). 
Mathematical literacy is mathematical knowledge, methods, and processes that are applied in various contexts in insight and thoughtful ways (Syahlan, 2015). Mathematical literacy includes mathematical reasoning and the use of mathematical concepts, procedures, facts, and tools to describe, explain, and predict phenomena (Jablonka, 2003).

Regarding mathematics literacy in international surveys, the country of Indonesia is ranked as being of reduced concern. OECD (Organization for Economic Cooperation and Development) as an organization that conducts periodic education surveys with its head office in Paris announces the results of the last PISA (Program for International Student Assessment) held in 2015. In the three-year study, the country of Indonesia is at ten lists of states that occupy the last position, which is ranked 62 out of 70 PISA participating countries with a score of 386 out of 500 total ratings (OECD, PISA 2015 Results in Focus, 2015). This certainly illustrates the low ability of students in mathematics literacy.

Seeing the low achievement of Indonesian education, especially in the field of mathematics on an international scale, the government has made efforts to improve and improve the quality of mathematics learning. One such improvement effort is the change of curriculum. In the latest changes, the curriculum has moved from KTSP to the 2013 Curriculum. Changes to the curriculum have been adapted to the evolving educational curriculum standards. Including changes to the curriculum of mathematics subjects. In it, there is a change in the part of the material that some of the content has been adapted from the domain of mathematical literacy. This is as stated by Nuraini (2017) in her research on the analysis of PISA model questions in the seventh-grade students' mathematics book, which explains that in the mathematics class VII student textbooks in the 2013 curriculum there are questions that correspond to the questions the PISA model is $34.60 \%$. That is, with the PISA model problems, it is expected that students will become more accustomed to dealing with everyday issues that require high reasoning.

Based on the description above, the problem formulations in this study are: 1) What is the level of metacognition of students in solving mathematical problems? 2) What is the level of student metacognition in mathematics literacy? 


\section{METHOD}

This study uses qualitative methods with descriptive research design and case studies. The focus of this research is on the level of students' metacognition in problem-solving and mathematical literacy. This research was carried out in Palimanan Public Middle School 3 2018/2019 academic year. The research subjects in this study were obtained based on the consideration of mathematics teachers. Considering the research time and suggestions from the teacher, only three students from class VII C were selected, with each student having different learning outcomes from each other.

The student selection process is based on the grouping of students which is carried out using the standard deviation formula with the following Catagory (Wendt, I., \& Carl, 1991):

Table 1 Category for selecting research subjects

\begin{tabular}{|c|l|}
\hline Category & \multicolumn{1}{|c|}{ Explanation } \\
\hline High & $\begin{array}{l}\text { Students who score more than or equal the average score } \\
\text { plus the standard deviation }(x \geq \bar{x}+S D)\end{array}$ \\
\hline Middle & $\begin{array}{l}\text { Students who score between the average scores minus the } \\
\text { standard deviation and the average score plus the standard } \\
\text { deviation }(\bar{x}-S D<x<\bar{x}+S D)\end{array}$ \\
\hline low & $\begin{array}{l}\text { Students who score below or equal the average score are } \\
\text { reduced by the standard deviation }(x \leq \bar{x}-S D)\end{array}$ \\
\hline
\end{tabular}

Data collection instruments used in this study were tests and interviews. The test used in this study is an essay. The test is divided into two parts, namely six questions for problem-solving tests and six items for mathematics literacy tests. The test is used to group students into high, medium, and low groups and to determine the level of metacognition of each group. Before it is used in the field, the instrument is validated by two lecturers and one mathematics teacher. Then, the instrument was tested, and the results were analyzed using Anates V4 software. After analyzed, it was 
found that the reliability of the questions compiled was high with a validity coefficient of 0.99 .

In this study, all students were given tests with the same material, namely social arithmetic. The test takes the form of an essay totaling six problem-solving questions and six mathematical literacy questions. The results of the test scores will be grouped according to the order of the largest to the smallest scores. It aims to determine students included in groups with high scores, medium scores, and low scores.

After grouping, three students were chosen as representatives of each group, and then interviews were conducted to confirm matters relating to student work outcomes on problem-solving tests and mathematics literacy. The interview used is unstructured. In the interview, the results of student work were matched with criteria for indicators of metacognition levels (Laurens, 2010; Fauziyah, 2011; Mahromah \& Manoy, 2013). The indicators for the level of metacognition indicators can be seen in the following table.

Table 2 Indicators for metacognition levels

\begin{tabular}{|c|l|}
\hline Indicator & \multicolumn{1}{c|}{ Explanation } \\
\hline Tacit Use & $\begin{array}{l}\text { Planning: Students cannot explain what is known and asked } \\
\text { Monitoring: Students do not show any awareness of what is being } \\
\text { monitored } \\
\text { Assessment: Students do not evaluate }\end{array}$ \\
\hline Aware Use & $\begin{array}{l}\text { Planning: Students can only explain part of what is done } \\
\text { Monitoring: Students are aware of some of the mistakes made but } \\
\text { cannot correct them } \\
\text { Assessment: Students show the existence of evaluation activities, } \\
\text { but are not sure of the results of their work }\end{array}$ \\
\hline Strategic Use & $\begin{array}{l}\text { Planning: Students can mostly understand and explain the } \\
\text { problems faced } \\
\text { Monitoring: Students are aware of errors, and some can correct }\end{array}$ \\
\hline
\end{tabular}




\begin{tabular}{|l|l|}
\hline Reflective Use & $\begin{array}{l}\text { Planning: Students as a whole understand the problem and can } \\
\text { explain it well } \\
\text { Monitoring: Students can apply the same concept/strategy to other } \\
\text { problems }\end{array}$ \\
Assessment: Students evaluate every step that is done well
\end{tabular}

In this study using two types of data sources, namely primary data and secondary data. Primary data in this study are data obtained through tests, while secondary data are literature review and interview results. Data analysis techniques used in this study used the data analysis technique of Miles and Huberman (1994), namely data reduction, data display, and conclusion drawing.

\section{RESULTS AND DISCUSSION}

\section{Results}

Livingston (2003) states metacognition as thinking about one's thinking or knowledge about one's thinking process. In line with that, Ormrod (2008) states that metacognition is thinking about thinking. Metacognition involves the learner's understanding and beliefs about his cognitive process and the learning material to be learned, as well as his conscious efforts to engage in behavioral and thinking processes that will enhance his learning and memory. Thus, it can be understood that metacognition is awareness, consideration, control of one's thought processes, and strategies.

Polya (1973) defines problem-solving as an attempt to find a way out of difficulty to achieve a goal that cannot be completed immediately. Meanwhile, according to Bell (1978) problem solving is defined as an effort to improve the ability to analyze and use it in different situations. Thus, it can be understood that problem- 
solving is an attempt made to find concepts/facts and solutions to the issues being faced.

After conducting a field study, based on the provision of questions in class VIIC SMP 3 Palimanan obtained three groups in each test. In the problem-solving test received seven students who have high learning outcomes, 16 students who have moderate learning outcomes, and nine students who have low learning outcomes. While the mathematics literacy test obtained five students, who have high learning outcomes, 20 students who have medium learning outcomes, and seven students who have low learning outcomes. Based on the grouping, the results of student work are analyzed and matched with indicators of the level of metacognition, to obtain the data distribution of students' level of metacognition in solving problems such as Figure 1 below.

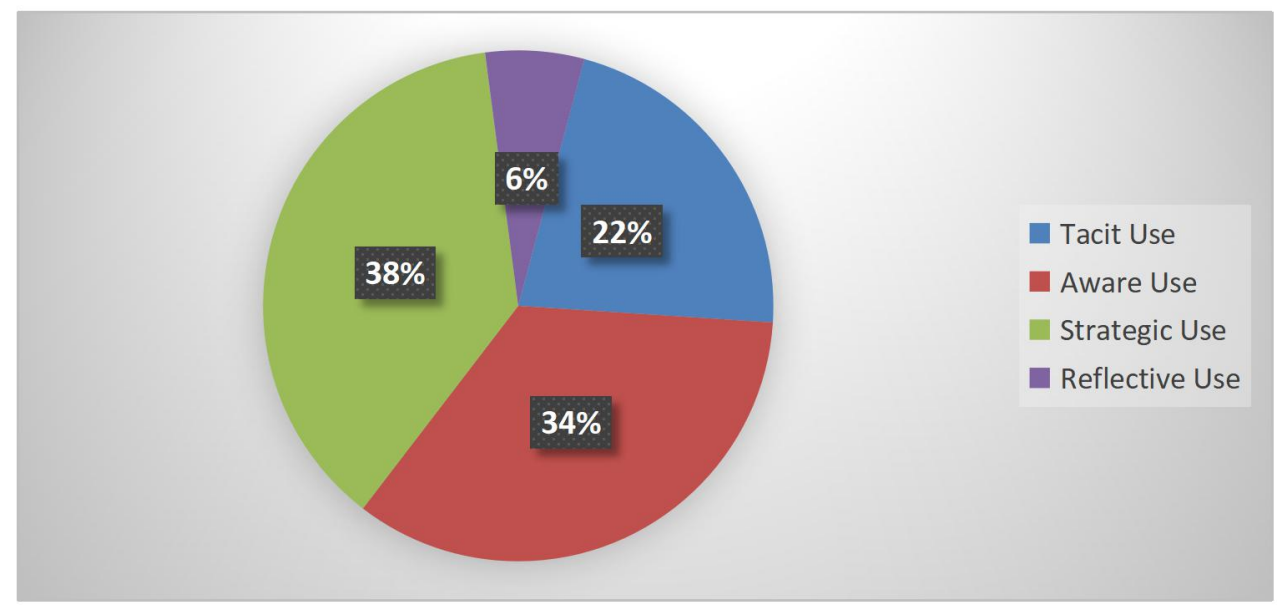

Figure 1. Distribution of students' level of metacognition in problem-solving

Based on Figure 1, it can be seen that in the math problem solving test obtained by students with a metacognition rate of as much as $22 \%$ ( 7 student), students with an Aware Uses metacognition rate of 34\% (11 student), students with a Strategic Uses metacognition rate of $34 \%$ (12 student), and students are at the level of metacognitive Reflective Uses as much as 6\% (2 students). This shows that the distribution of the level of metacognition in mathematical problem solving is mostly at the level of Strategic Use metacognition.

According to the OECD (2017), mathematical literacy is the capacity of students to formulate, apply, and interpret mathematics in various contexts that include 
mathematical reasoning and use mathematical concepts, procedures, facts, and tools to describe, explain, and predict phenomena. Agreeing with that, Ojose (2011) said that mathematical literacy is knowledge to know and apply a mathematical basis in everyday life. Thus, it can be understood that mathematical literacy is a person's ability to apply various mathematical concepts in everyday life. Meanwhile, the distribution of students' level of metacognition in mathematics literacy can be seen in Figure 2 below.

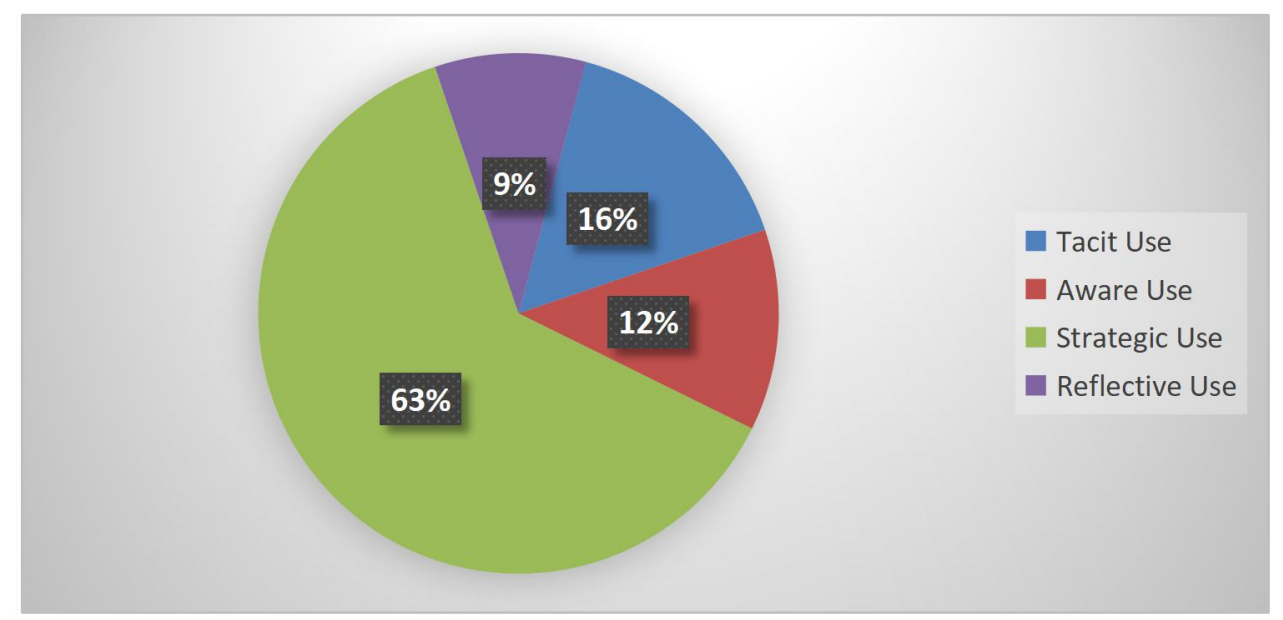

Figure 2 distribution of students' level of metacognition in mathematics literacy

Based on Figure 2, it can be seen that in the mathematics literacy test obtained by students with a metacognition rate as much as $16 \%$ (5 students), students with a metacognition level of Aware Uses as much as 12\% (4 students), students with a Strategic Uses metacognition rate of as much as 63\% (20 students), and students with a Reflective Uses metacognition rate of 9\% (3 students). As with problem-solving, the distribution of the level of metacognition in mathematics literacy is most dominant at the level of metacognition Strategic Use.

\section{Discussion}

Based on the acquisition of student learning outcomes and consideration of mathematics teachers, only three students were made as research subjects, namely students with high learning outcomes (high groups), students with medium learning outcomes (middle groups), and students with low learning outcomes (low groups).

\section{a. Metacognition of High Group Students}


In this study, high group students have quite good results when solving problems in social arithmetic material. This is in line with research conducted by Nurmaliah (2009) and Sophyaningtias \& Sugiarto (2013), which states that students who have high learning outcomes have high levels of metacognition as well. Here are the results of student responses and analysis of high-level student metacognition.

Table 3. Results of high-level student metacognition

\begin{tabular}{|c|c|c|}
\hline & Mathematical Problem Solving & Mathematical Literacy \\
\hline & 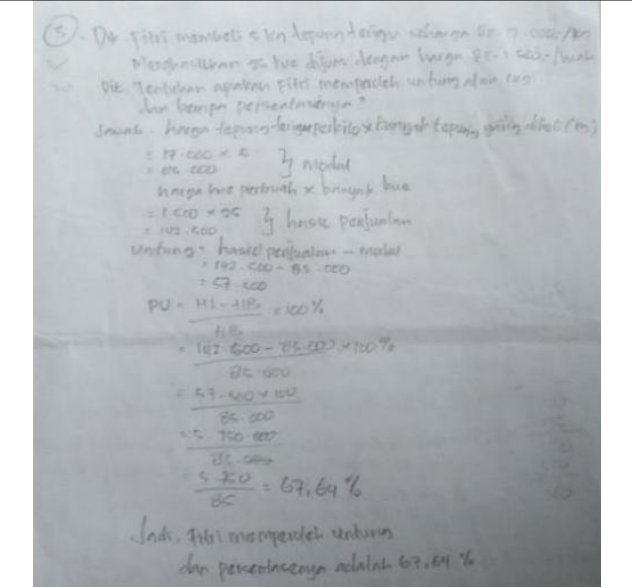 & 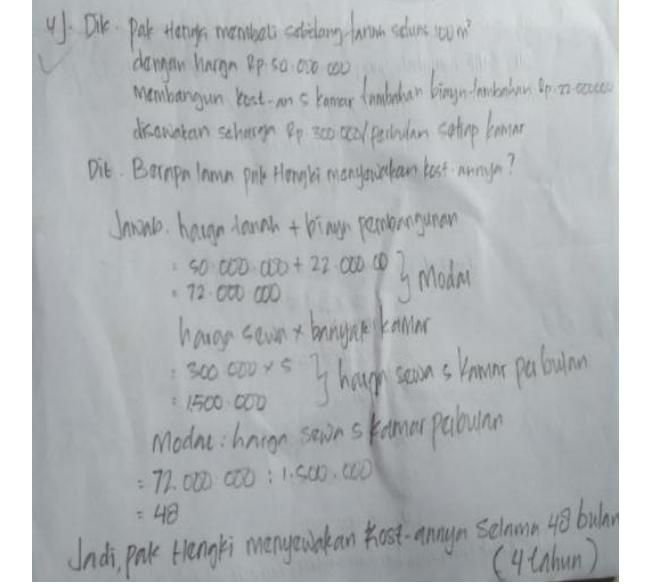 \\
\hline & $\begin{array}{l}\text { Understand the problem well } \\
\text { because it can identify relevant } \\
\text { information in the question, know } \\
\text { the ways used to solve the problem, } \\
\text { explain the strategies used to solve } \\
\text { the problem, apply the same } \\
\text { approach to other problems, and } \\
\text { evaluate each step made. }\end{array}$ & $\begin{array}{l}\text { Understand the problem well } \\
\text { because it can identify important } \\
\text { information in the problem, find out } \\
\text { the ways used to solve the problem, } \\
\text { explain the strategies used to solve } \\
\text { the problem, apply the same strategy } \\
\text { to other problems, realize the concept } \\
\text { errors and can correct them, and } \\
\text { evaluate each step which is made. }\end{array}$ \\
\hline
\end{tabular}

From the sequence of metacognitive activities above, high group students both in solving mathematical problems and in mathematical literacy can be classified at the level of metacognition "Reflective Use." This is also in line with research conducted by Nurjanah (2017) that students in the high group are at the level of Metacognition Reflective Use.

High group students as a whole can express problems clearly (write what is known and asked), know how to solve the problem (write the formula used at 
each step of the answer), apply the same strategy to other problems, realize calculation errors and correct them, as well as evaluating after working on the questions (write the word "finished" at the end of each answer, but the evaluation is still not thorough).

\section{b. Metacognition of middle group student}

Students in the middle group as a whole have good results when solving the given problem. In this case, students with learning outcomes are doing metacognition activities which include planning, monitoring, and evaluation. This is in line with research conducted by Aini (2017) that students with the ability to carry out metacognitive activities include planning, monitoring, and evaluating mathematics problem-solving. Here are the results of student answers and metacognition level analysis of middle group students..

Table 4. Results of middle group student metacognition

\begin{tabular}{|c|c|c|}
\hline & Mathematical Problem Solving & Mathematical Literacy \\
\hline 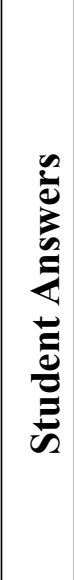 & 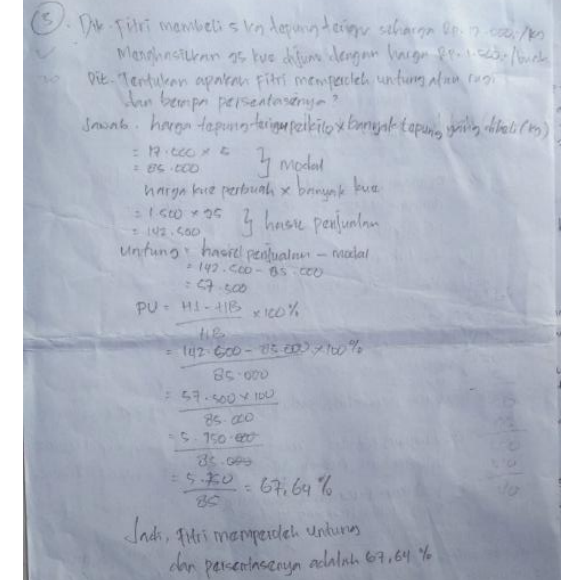 & 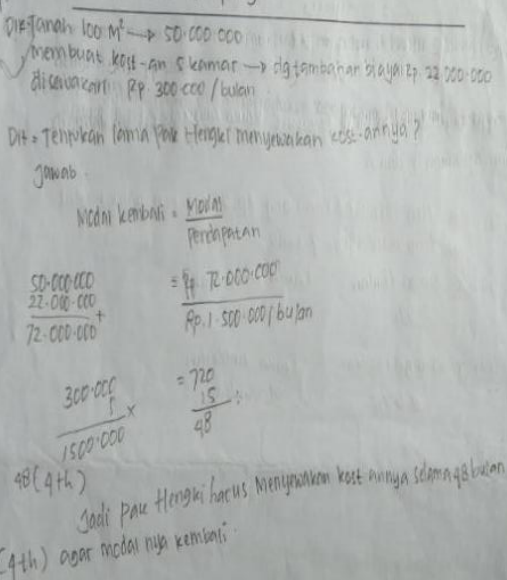 \\
\hline
\end{tabular}




\begin{tabular}{|c|c|c|}
\hline & $\begin{array}{l}\text { Understanding the problem because } \\
\text { it can express clearly, have doubts } \\
\text { about formulas and how to count, } \\
\text { do not experience difficulty and } \\
\text { confusion in finding equations and } \\
\text { how to calculate, can explain most } \\
\text { of what is written, realize } \\
\text { misconceptions and how to count, } \\
\text { give reasons that support his } \\
\text { thinking, and do evaluation but not } \\
\text { sure of the results obtained. }\end{array}$ & $\begin{array}{l}\text { Understanding the problem because } \\
\text { it can reveal clearly, do not } \\
\text { experience difficulties and confusion } \\
\text { to find formulas and how to } \\
\text { calculate, can explain most of what is } \\
\text { written, realize misconceptions and } \\
\text { how to calculate, give reasons that } \\
\text { support his thinking, (unclear to the } \\
\text { results obtained, do the evaluation } \\
\text { but not sure about the results } \\
\text { obtained. }\end{array}$ \\
\hline
\end{tabular}

From the sequence of metacognitive activities above, group students both in solving mathematical problems and in mathematical literacy can be classified at the level of metacognition "Strategic Use." This is in line with research conducted by Nurjanah (2017), which states that students who have learning outcomes are at the Strategic Use metacognition level. In this case the group students are being able to express the problem clearly (write what is known and asked), can find a formula and how to calculate it, be aware of how to calculate it quite well, and do an evaluation but are not sure of the results obtained (write the word 'so' but not careful with the results of the answer).

\section{c. Metacognition of Low group student}

Low group students have poor results compared to middle group students and high group students. The subject can only solve problems that are classified as easy. This is in line with research conducted by Irham (2017) than students in the low group are only able to involve their meta-logic in easy problems, whereas in moderate and challenging problems, the subject fails to include their meta-logic. Here are the results of student answers and analysis of the metacognition level of low group students.

Table 4. Results of low group student metacognition

\begin{tabular}{|l|l|l|}
\hline & Mathematical Problem Solving & Mathematical Literacy \\
\hline
\end{tabular}




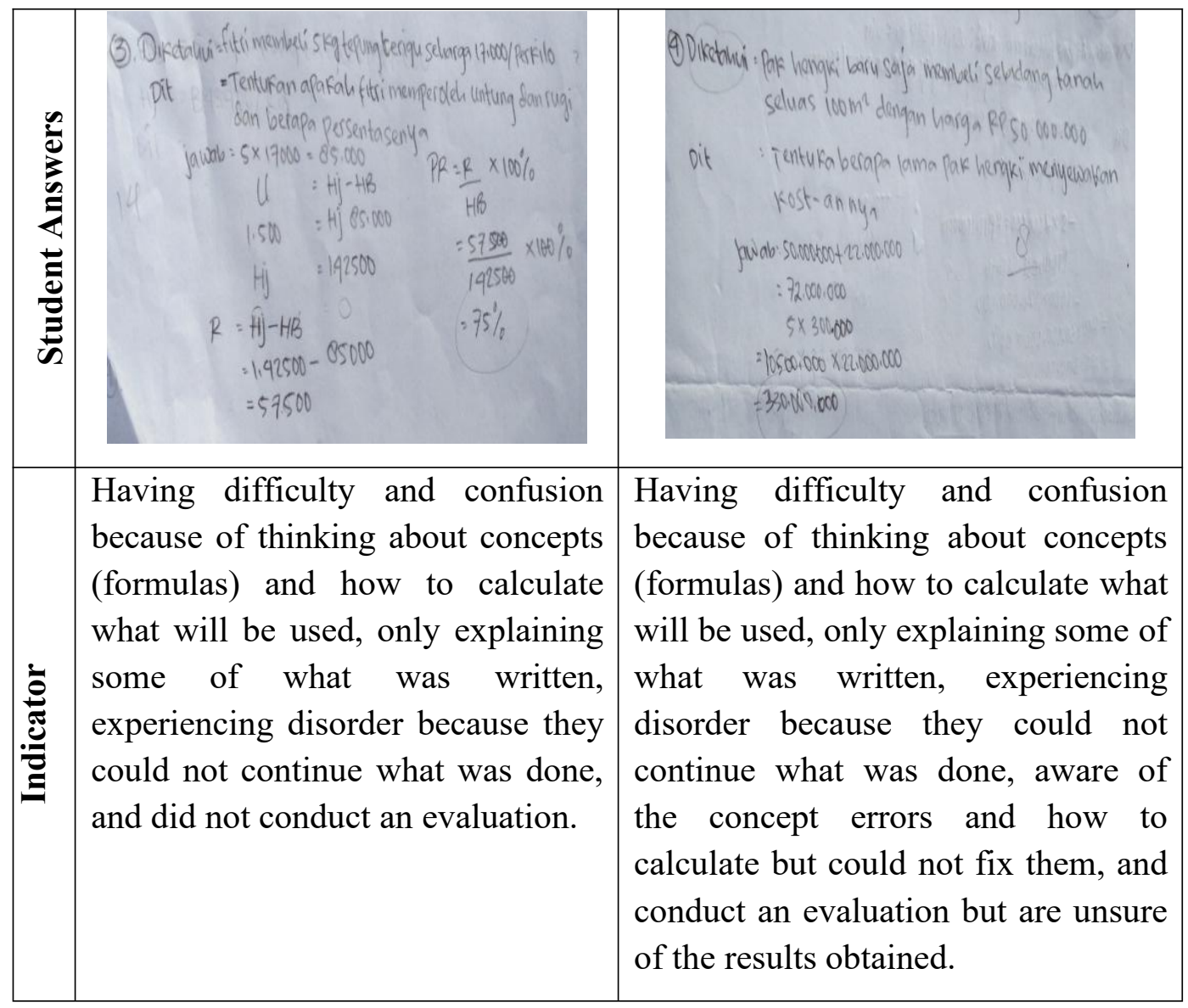

From the sequence of metacognitive activities above, low-group students in mathematical problem solving are classified at the level of metacognition "Tacit Use." This is in line with research conducted by Mahromah \& Manoy (2013) than students in the low group are at the Tacit Use metacognition level. In this case, the subject can only explain a portion of what was written, experiencing confusion in thinking about concepts (formulas), and not evaluating the results obtained (not writing the word 'finished'), while in mathematical literacy the subject is classified at the level of metacognition "Aware Use." That is because the item can only explain part of what is written, experience confusion in thinking of concepts (formulas), cannot continue what is done, and evaluates the results obtained but is inconsistent.

\section{d. The metacognition comparison of mathematical problem-solving with mathematical literacy}




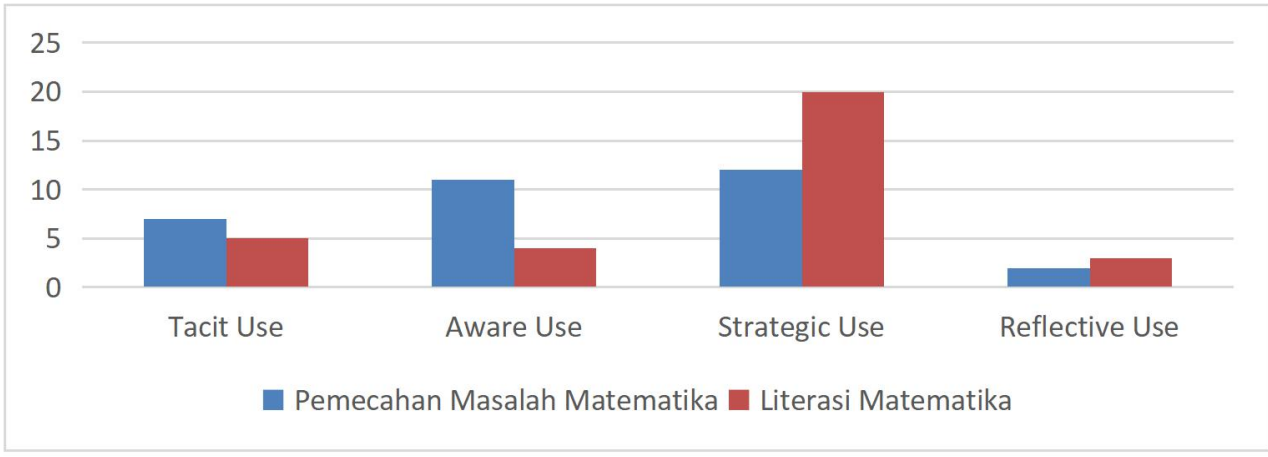

Figure 3. The metacognition comparison of students

Based on Figure 3, it can be seen that the distribution of metacognition levels in mathematical problem solving and mathematical literacy has different results in each of the metacognition level categories. Students who are classified into the level of metacognition Tacit Use, mostly derived from the effects of problem-solving tests. Just as with the level of metacognition Tacit Use, at the level of metacognition Aware Use also most students come from the results of problem-solving tests. Whereas at the level of Strategic Use metacognition, most students come from the effects of mathematics literacy tests. Finally, the level of Reflective Use metacognition, only a few students can reach this level. Thus, mathematical problem solving and mathematical literacy do not have a significant relationship to the distribution of levels of metacognition..

\section{CONCLUSION}

Based on the results of data analysis and discussion that has been obtained, it is found that the level of student metacognition in problem-solving and mathematical literacy has quite diverse effects. In solving mathematical problems, it is found that students with high learning outcomes (high groups) are at the level of metacognition Reflective Use. Students with moderate learning outcomes (medium group) are at the Strategic Use metacognition level. Students with low learning outcomes (low groups) are at the Tacit Use level of metacognition. Meanwhile, the level of metacognition of students in mathematical literacy is not much different from the level of metacognition in solving mathematical problems. Students with high learning outcomes (high groups) 
are at the level of Reflective Use metacognition. Students with moderate learning outcomes (medium group) are at the Strategic Use metacognition level. Students with low learning outcomes (low groups) are at the Aware Use metacognition level. Overall the level of metacognition of students both in solving mathematical problems and in mathematical literacy is at the level of metacognition Strategic Use Based on the results of data analysis, and discussion that has been obtained, the level of student metacognition in problem-solving and mathematical literacy has quite diverse effects. In solving mathematical problems, it is found that students with high learning outcomes (high groups) are at the level of metacognition Reflective Use. Students with moderate learning outcomes (medium group) are at the Strategic Use metacognition level. Students with low learning outcomes (low groups) are at the Tacit Use level of metacognition.

Meanwhile, the level of metacognition of students in mathematical literacy is not much different from the level of metacognition in solving mathematical problems. Students with high learning outcomes (high groups) are at the level of Reflective Use metacognition. Students with moderate learning outcomes (medium group) are at the Strategic Use metacognition level. Students with low learning outcomes (low groups) are at the Aware Use metacognition level. Overall the level of metacognition of students both in solving mathematical problems and in mathematics literacy is at the level of strategic use metacognition.

\section{REFERENCE}

Alfiyah, N. (2014). Identifikasi Kesulitan Metakognisi Siswa dalam Memecahkan Masalah Matematika. MATHEdunesa, 3(2).131-138

Bell, F. H. (1978). Teaching and learning mathematics (in secondary schools). WC Brown Company.

Fauziyah, N. (2011). Identifikasi Metakognisi dalam Memecahkan Masalah Matematika Berbentuk Soal Cerita. Surabaya: UNESA

Flavell, J. H. (1979). Metacognition and cognitive monitoring: A new area of cognitive-developmental inquiry. American psychologist, 34(10), 906.

Gardner, H. E. (2000). Intelligence reframed: Multiple intelligences for the 21st century. Hachette UK.

Jablonka, E. (2003). Mathematical literacy. In Second international handbook of mathematics education (pp. 75-102). Springer, Dordrecht. 
Karamarski, B. (2017). Developing a pedagogical problem solving view for mathematics teachers with two reflection programs. International Electronic Journal of Elementary Education, 2(1), 137 153.

Kazemi, F., Yektayar, M., \& Abad, A. M. B. (2012). Investigation the impact of chess play on developing meta-cognitive ability and math problem-solving power of students at different levels of education. Procedia-Social and Behavioral Sciences, 32, 372-379.

Laurens, T. (2010). Penjenjangan Metakognisi Siswa yang Valid dan Reliabilitas. Jurnal Pendidikan Dan Pembelajaran (JPP), 17(2), 201-211.

Livingston, J. A. (2003). Metacognition : An Overview. New York: The State University of New York

Mahromah, L. A., \& Manoy, J. T. (2013). Identifikasi Tingkat Metakognisi Siswa dalam Memecahkan Masalah Matematika Berdasarkan Perbedaan Skor Matematika. MATHEdunesa, 2(1).1-8

Marlina, L. (2013). Penerapan Langkah Polya dalam Menyelesaikan Soal Cerita Keliling dan Luas Persegi Panjang. Jurnal Elektronik Pendidikan Matematika Tadulako, 1(1), 43-52.

Matlin, M. W. (2009). Cognition. New York: John Wiley\&Sons.

Maulidyawati, D., \& Irham, M. (2018). Analisis Metakognisi Peserta Didik dalam Pemecahan Masalah pada Materi Turunan. Kreano, Jurnal Matematika Kreatif-Inovatif, 9(1), 84-92.

Miles, M. B., Huberman, M. A., \& Saldana, J. (1994). Qualitative analysis: An expanded sourcebook. Thousand Oaks, CA: Sage.

Murtiyasa, B. (2016). Isu-Isu Kunci dan Tren Penelitian Pendidikan Matematika. Konferensi Nasional Penelitian Matematika dan Pembelajarannya (KNPMP I), 1-10

Nuraini, N., \& Rejeki, S. (2017). Analisis Soal Model Pisa Dalam Buku Siswa Matematika Kelas Vii Smp/Mts Semester I Kurikulum 2013 (Doctoral dissertation, Universitas Muhammadiyah Surakarta).

Nurjanah, A. I. (2016). Analisis Level Metakognitif Siswa dalam Memecahkan Masalah pada Materi Kelarutan dan Hasil Kali Kelarutan (Bachelor's thesis, jakarta: FITK UIN Syarif Hidayatullah Jakarta).

Nurmaliah, C. (2009). Analisis keterampilan metakognisi siswa SMP Negeri di Kota Malang berdasarkan kemampuan awal, tingkat kelas, dan jenis kelamin. Jurnal Biologi Edukasi, 1(2), $18-21$.

Nuurjannah, P. E. I., Hendriana, H., \& Fitrianna, A. Y. (2018). Faktor Mathematical Habits of Mind dan Kemampuan Literasi Matematis Siswa SMP di Kabupaten Bandung Barat. Jurnal Mercumatika: Jurnal Penelitian Matematika dan Pendidikan Matematika, 2(2), 51-58.

OECD. (2015). PISA 2015 Results in Focus. Paris: OECD.

OECD. (2017). PISA for Development Assessment and Analytical Framework : Reading, Mathematics and Science. Paris: OECD Publishing

Ojose, B. (2011). Mathematics literacy: Are we able to put the mathematics we learn into everyday use. Journal of Mathematics Education, 4(1), 89-100.

Ojose, B. (2011). Mathematics literacy: Are we able to put the mathematics we learn into everyday use. Journal of Mathematics Education, 4(1), 89-100.

Ormrod, E. J. (2008). Psikologi Pendidikan. Membantu Siswa Tumbuh dan Berkembang jilid 1. Jakarta: Erlangga 
Polya, G. (2004). How to solve it: A new aspect of mathematical method (No. 246). Princeton university press.

Purnaningsih, N. E. (2015). Profil Metakognisi Siswa Dalam Memecahkan Masalah Matematika Ditinjau Berdasarkan Tipe Kepribadian Koleris dan Phlegmatis. MATHEdunesa, 3(3). 32-38

Schoenfeld, A. H. (1992). Learning to think mathematically: Problem solving, metacognition, and sense making in mathematics. Handbook of research on mathematics teaching and learning.

Sophianingtyas, F. S. (2013). Identifikasi Level Metakognitif Siswa dalam Memecahkan Masalah Materi Perhitungan Kimia (Identification of Students'metacognitive Level in Solving Stoichiometry Problem). UNESA Journal of Chemical Education, 2(1).21-27

Styawati, R. D., \& Nursyahida, F. (2017). Profil Kemampuan Literasi Matematika Siswa Berkemampuan Matematis Rendah Dalam Menyelesaikan Soal Berbentuk PISA. AKSIOMA: Jurnal Matematika dan Pendidikan Matematika, 8(2), 33-42.

Suraji, S., Maimunah, M., \& Saragih, S. (2018). Analisis Kemampuan Pemahaman Konsep Matematis dan Kemampuan Pemecahan Masalah Matematis Siswa SMP pada Materi Sistem Persamaan Linear Dua Variabel (SPLDV). Suska Journal of Mathematics Education, 4(1), 9-16.

Wendt, I., \& Carl, C. (1991). The statistical distribution of the mean squared weighted deviation. Chemical Geology: Isotope Geoscience Section, 86(4), 275-285.

Winarso, W. (2014). Problem solving, creativity dan decision making dalam pembelajaran matematika. Eduma: Mathematics Education Learning and Teaching, 3(1).1-16

Yarmayani, A. (2016). Analisis Kemampuan Pemecahan Masalah Matematis Siswa Kelas XI MIPA SMA Negeri 1 Kota Jambi. Jurnal Ilmiah DIKDAYA, 12-19 